\title{
Parental Intentions to Wean Following Advances in Primary Prevention of Food Allergy
}

\author{
Ailish Breathnach ${ }^{1}$, Rosemary Geoghegan ${ }^{1}$, and Edina Moylett ${ }^{1}$ \\ ${ }^{1}$ National University of Ireland Galway School of Medicine
}

November 11, 2020

\section{Hosted file}

Main_text_file.pdf available at https://authorea.com/users/374780/articles/492220-parentalintentions-to-wean-following-advances-in-primary-prevention-of-food-allergy 